\title{
History and Fiction: An Uneasy Marriage?
}

\author{
J. Thomas Lindblad \\ Leiden University, the Netherlands/Universitas Gadjah Mada, Indonesia \\ E-mail: thomaslindblad@hotmail.com
}

\begin{abstract}
This essay discusses the relationship between history as a science and fiction as a genre of literature. It starts with a brief digression on the characteristics and pitfalls of the historical novel, including its development over time. Past experience is highlighted with the aid of a selection of acknowledged novelists making intensive use of historical information. Recent new trends are illustrated by professional historians becoming novelists. A final section offers reflections on how to combine the demands of authenticity in history with the demands of drama in literary fiction.
\end{abstract}

Keywords: historical fiction; research in history; literature; authenticity

\section{INTRODUCTION}

History and fiction have much in common but are not easily reconciled with one another. Both aim at recreating a reality and making it accessible to readers. History seeks to come as close as possible to truth, but fiction is by definition not truthful. Sources of inspiration and knowledge are different too. History is based on research, while fiction on imagination, on occasion spiced by personal memory. Good history is not boring, while fiction without drama does not appeal. This essay contains some reflections on how to combine the requirements of history as a science with the demands of drama inherent in fiction.

Historical fiction uses an actual historical past as the setting of the story, but it remains subject to the same conventions of drama applying to works of literature in general, including an internal logic, suspense and revelations. The logical point of departure for reflections on historical fiction as a literary genre is the historical novel that can draw on a long and distinguished history culminating in an increasing popularity in recent years. The first substantive section of this essay therefore focuses on the concept of the historical novel. Yet, it needs to be pointed out that this essay cannot possibly offer a full overview of the historical novel in its many shapes over the years. That is a topic in its own right, well covered in publications by others (Johnson, 2005, 2009; De Groot, 2010).

There is traditionally a strong tendency among writers of novels to refer to a historical past behind them as a tool to increase credibility of the plot and make the story more easily accessible to readers. This tendency finds its roots long before historical fiction emerged as an independent literary genre in the nineteenth century. The second section of my essay offers a number selected examples of novelists turning to history. Again, it must be underscored that there is no pretension of offering anything resembling an exhaustive coverage.

Historians have long been inclined to shy away from writing fiction, at any rate fiction applying the knowledge that they have themselves accumulated in professional capacity. But things are changing. Historians have in recent years increasingly joined the ranks of the historical novelists, often reaching a larger audience than with their monographs and scientific articles. After all, as award-winning novelist Hilary Mantel noted, 'fiction is commonly more persuasive than history texts' (Mantel, 2009a). The third section of this essay therefore focuses on historians turning 
into novelists; again, it goes without saying, without the pretension of presenting more than just a number of selected examples.

But how can we combine history and fiction in such a way that the result is commensurate with both history as a science and fiction as an artistic expression? In the final sections of this essay, some thoughts are promulgated on how to accomplish such an outcome. It should be noted that these are personal reflections that may or may not apply to others interested in venturing on the exciting exercise of writing historical fiction.

\section{THE HISTORICAL NOVEL}

At first sight, it would appear easy enough to come up with a definition of what constitutes a historical novel. The shortest possible definition is simply: 'fiction set in the past' (Johnson, 2002). This definition is endorsed by the Historical Novel Society, a nonprofit international organization founded in 1997 with chapters in the United Kingdom, the United States and Australia. The problem with that definition is that it is so broad that virtually anything can fit in under this label. Jerome de Groot, main chronicler of the historical novel, argues that such a broad definition runs the risk of becoming meaningless because there is too much overlap with other genres of literature (De Groot, 2010: 50).

The conventional definition inevitably begs the question: How far back do we need to go to find the appropriate historical reality? I spotted at least five different answers in the extensive secondary literature about the historical novel on Internet. The first answer is commonly cited: the story should be written at least fifty years after the event. This in turn suggests a different criterion or second answer to the same question: the author of the story should not have been alive at the time of the event, or at any rate been able to witness it as an adult observer (Lee, no date). This implies yet another answer to the question, a third one: the author works from research, not from personal memory.

Counting backwards from the early twenty-first century, Sarah Johnson, book review editor for the Historical Novel Society, argues that the historical novel should be built around an event that occurred no later than in the middle of the twentieth century (Johnson, 2005: 1). This criterion, or fourth answer to the same question, is of course subject to change as time passes by. But not everybody agrees with these standpoints. Lynda Adamson, compiler of the main bibliographic reference work to the genre, reduces the time lag to twenty-five years (Adamson, 1999: xi). This criterion, or fifth answer, is obviously not compatible with the requirement that the author was not around at the time of the event.

But the historical novel is more than a story defined in terms of a time lag and an empirical foundation in research rather than imagination or personal memory. It aims at recreating a genuine historical reality in which the reader is immersed. The past is often likened with a foreign country, one well worth visiting, where some elements are familiar and others are not. A unique key feature of the historical novel, therefore, is attention to detail. This applies to how people were dressed, what they ate and drank, physical surroundings, even the smell in streets, the weather, means of transport and time required for travel, not to mention innumerable cultural traits, including vocabulary in speech and ways of thinking. Writers of historical novels and commentators on the genre generally agree that the details of the recreated historical reality should be factually correct. They are also acutely aware of the fact that readers of historical novels are frequently observant when it comes to detail. The fundamental issue of historicity or authenticity determines whether the story succeeds as a historical novel.

The historical novel remains a work of fiction with different aims and functions compared to a report on outcomes of historical research. The overall aim of a novel of short story is to entertain and inspire, to offer interesting insights and evoke emotions. This holds true for the historical novel as well, although the story can also serve as a source of information about realities of the past, provided the details are correct. The writer of the historical novel is compelled by the demands of fiction to take liberties with the historical reality. Time frames are compressed, actions and reactions are extrapolated from existing evidence, more drama is added if need be, while historical persons mix freely with fictitious personages. The historical novel struggles continuously with the tension between authenticity and fiction.

The position of the historical event itself in the story varies. It may serve as backdrop to a story of fiction, thus providing an interesting framework for dramatic action. It can also develop into the main target of the quest told by the fictional story, especially when the solution of a historical mystery is at stake. The main purpose can also be to portray a reality of 
the past, adding fictional elements to make the story more attractive to readers. Yet another aim can be to comment on today's world by offering an alternative perspective to life. The plot then needs to be geared towards themes relevant to present society in order to qualify as 'literary' (Johnson, 2002).

Surreptitiously, I add that the historical novel must not be confused with history-writing with an overt or hidden political purpose in order to, for instance, instill nationalist sentiments as has on many occasions happened in the past. The concept of the historical novel must also be kept apart from the invention of pseudo-facts with the intention of misinforming the public, a practice that regrettably seems to become increasingly popular.

Although having had predecessors since Greek and Roman times, the historical novel is generally seen to have emerged as an independent genre of literature in the early nineteenth century. The first work in the Western tradition was the novel Waverley (1814) by Sir Walter Scott, situated during the Jacobite rebellion in England in 1745. It was followed by Ivanhoe (1820) about the world of English knights in the twelfth century. Sir Walter Scott set an example for writers elsewhere. In the United States James Fenimore Cooper wrote The Last of the Mohicans (1826) about the indigenous Indian allies of both the British and the French while at war in the American colonies in 1757. In France Honoré de Balzac followed suit with Les Chouans (The Royalists, 1829) about an antirevolutionary uprising in France in 1799. A similar pioneering work appeared in the Russian literary scene's much later stage with Leo Tolstoy's monumental War and Peace (1869) about Tsarist Russia before and during Napoleon's invasion in 1812. The early history of the historical novel was succinctly analyzed by the Hungarian Marxist literary critic György Lukacs (Lukacs 1983).

The twentieth century saw several waves of a renewed interest in the genre. Examples include Thomas Mann's Buddenbrooks (1901) about a dynasty of German merchants in the mid-nineteenth century, Robert Graves with I Claudius (1934), the imagined autobiography of a Roman Emperor, and, of course, the historical crime fiction of Umberto Eco with The Name of the Rose (1980), featuring monks in Italy in the early fourteenth century.

Meanwhile, the genre of the historical novel expanded in several directions. A whole host of subgenres have seen the light, including documentary fiction, fictional biography, historical mystery, historical romance, pirate fiction, alt-history (presuming an alternative outcome of pivotal events), as well as separate branches attuned to the taste of young adults and children. The tendency towards expansion and diversification only gained momentum after the turn to the twenty-first century. There seems to have been a stronger urge than ever to resolve mysteries in the past by using the tool of the historical novel. One commentator remarked: 'The past decade [2000-2010] has seen an explosion in both quantity and quality. Historical mysteries nowadays cover a wide scope of human experience' (Picker, 2010).

Despite widespread appreciation by the general public, the historical novel continues to be haunted by a lack of respectability. In the eyes of literary critics, these novels are supposed to be less wellwritten than genuine literary function when it comes to style and drama. At the same time, professional historians are quick to point out factual inaccuracies and misinterpretations of historical events. The status of the historical novel remains low with those writing such fiction easily dismissed as amateurs. A glance at the current mass of Internet articles on history and fiction suggests that increasing popularity in recent years has done little to improve the reputation of the historical novel.

But the prospects for change are promising, considering developments in both the older tradition of novelists using historical materials and a more recent tendency among historians to switch from nonfiction to fiction. Such developments are touched upon in the next two sections.

\section{NOVELISTS TURNING TO HISTORY}

History offers a virtually limitless wealth of interesting material for good fiction, provided the historical information is treated properly from the perspective of fiction as well as history. Examples abound from centuries of a long literary tradition and any selection is likely to contain an element of arbitrariness. The intention of the limited selection presented here is to illustrate the effectiveness of incorporating history in fiction. In addition, I wish to bring to attention some examples that may be less well-known in the general discourse on the historical novel, which, admittedly, has largely been conducted within the Anglo-Saxon world of letters. For this purpose, eight novelists were selected. They all published significant work in this genre during the past one hundred odd years. The novelists represent literary tradition in four countries: 
the United Kingdom (3), the Netherlands (2), Indonesia (2) and Sweden (1). The gender distribution is even: four men and four women.

W. Somerset Maugham (1874-1965) became known as the commercially most successful of English short story writers ever. His historical fiction was based on extensive travel in the 1920s in the British colonies in Southeast Asia. The resulting short stories are set among English expatriates living and working in the Federated Malay States (Selangor, Perak, Negri Sembilan, and Pahang) in the late-colonial period. His short stories were published in two volumes. The first one was titled The Casuarina Tree (1926) and included the stories: 'Before the Party', 'P. \& O.', 'The Outstation', 'The Force of Circumstance', 'The Yellow Streak' and 'The Letter'. The second volume, Ah King (1933), comprised the stories: 'Footprints in the Jungle', 'The Door of Opportunity', 'The Vessel of Wrath', 'The Book-Bag', 'The Back of Beyond' and 'Neil MacAdam'.

The author was keen to expose arrogance and hypocrisy among the British expats. In an added postscript, he claimed that the characters were all fictitious. Nevertheless, both collections of short stories were very negatively received by the expatriates in British Malaya. The expat community felt scandalized and accused Maugham of having abused his position as an honored guest to collect ordinary gossip and reproduce this information in best-selling short stories. He was no longer welcome as a guest (Hastings, 2009). Viewed from a broader perspective, Maugham's short stories remain highly informative about the inherent peculiarities of colonial society.

The context of colonialism plays a key role in part of the work by the Dutch novelist Hella Haasse (1918-2011), who herself spent her entire childhood in the then Netherlands Indies. In her debut novel, titled Oeroeg (1948), she uses the Indonesian Revolution in the second half of the 1940s as the backdrop to the touching story of the friendship between two boys, one Dutch, the other Indonesian, who end up on opposite sides in the Dutch-Indonesian conflict. The characters are fictitious, while the historical setting is not. The novel offers unique insights into the extraordinary social relations evolving in Indonesia as Dutch colonialism in Indonesia came to a conclusion. At a far later stage, the story became a major movie (1993) and was translated into both Indonesian (2009) and English (2013).

Several decades after Oeroeg, Hella Haasse returned to her original Indonesian context with the novel The Tea Lords (2010), which originally appeared in Dutch in 1992. This is the account of the life of the planter Rudolf Kerkhoven who ran a tea estate in West Java in the 1870s and 1880s. It is a genuinely historical novel, based on preserved letters and other primary documentation. There are no fictitious characters involved. It is probably as close to a work of historical non-fiction as a historical novel can become, rich in authentic detail but lacking the emotional drama of Oeroeg. One reviewer designated The Tea Lords as 'half a novel' but at the same time 'a marvelously achieved improvisation' testifying to the greatness of Hella Haasse as a novelist (Evans, 2010).

Hella Haasse became the grand old lady of Dutch literature, inspiring scores of writers of a younger generation. One talented disciple in the genre of young adult fiction is Floortje Zwigtman (born 1974). She compiled a trilogy on the life of a gay young man in the shadow of the sodomy process against Oscar Wilde in 1895. The story is based on meticulous archival research in London. It liberally mixes historical persons and fictitious figures. The result is a convincing combination of a tangible historical reality with personal drama. The three volumes appeared in 2005-2010 with titles that in improvised translation would be rendered as 'Tricks of the Trade', 'Response' and 'Mirror Boy'. The trilogy urgently needs to be translated and made accessible to an international readership.

The foremost historical novelist in Indonesian letters was without doubt Pramoedya Ananta Toer (1925-2006), the sole Indonesian ever to be nominated for the Nobel Prize in literature. His most famous and most historical work is the Buru tetralogy, written during imprisonment on the island of Buru in East Indonesia. This is a series of four historical novels, in English translation titled Earth of Mankind, Child of All Nations, Footsteps and House of Glass (19801988). The setting is colonial Indonesia in the early twentieth century at the time of the birth and early development of the Indonesian nationalist movement. The protagonist in the first volumes is known by his slightly derogative nickname Minke and said to have been born on the very same day as Dutch Queen Wilhelmina (31 August 1880). Pramoedya later explained that Minke is based on an actual historical person, the journalist Tirto Adhi Surjo (1880-1918), who played an important role in the early nationalist movement. Other personages are mostly fictitious (Kurniawan, 2006). The early novels in particular 
provide us with an acute understanding of the complex social relations between the young nationalist from the Javanese elite and the poor people in the rural Java he is supposed to deliver from the yoke of Dutch colonialism.

One of Pramoedya's disciples is Eka Kurniawan (born 1975), who not only wrote about Pramoedya himself but also similarly used a historical context in his work of fiction. His most famous work, in English translated as Beauty is a Wound, is set in the violent times of the Japanese occupation (1942-1945) and the Indonesian mass killings (1965/66). The characters are fictitious, but the surroundings are not, just like in Hella Haasse's Oeroeg. In addition, male characters are depicted in such a way as to represent a variety of violent figures in Indonesian history, notably the brutal military man, the fanatic Marxist and the criminal thug. A flavor of surrealism permeates the plot, which brings the novel closer to fiction than to history.

Sixteenth-century Tudor England has never ceased to appeal to British writers. Hilary Mantel (born 1952) became famous with the novel Wolf Hall (Mantel, 2009b) for which she received the Man Booker Prize. It is a fictionalized biography of the powerful first minister of Henry VIII, Thomas Cromwell. The novel conveys a significantly more sympathetic impression of the controversial statesman than what is conventionally given in non-fiction historical texts. In addition, Wolf Hall treats the readers to a vivid description of what life was like in early sixteenth-century England. The sequel, titled Bring Up the Bodies (2012), follows Cromwell during the short period when Anne Boleyn was Henry VIII's queen. Again, Hilary Mantel was awarded the Man Booker Prize, allegedly the first woman ever to gain this distinction twice. A third and final volume on the life of Thomas Cromwell is scheduled to appear in 2019 under the title The Mirror and the Light. Both Wolf Hall and Bring Up the Bodies have been adapted for television.

Another much favored period among British novelists is the first half of the nineteenth century, encompassing both the Regency under the later George IV and the start of the Victorian era. Daisy Goodwin (born 1961), a television and arts producer with a degree from Cambridge, was one of those who allowed themselves to be inspired by the young Queen Victoria, ascending to the throne in 1837 at the age of eighteen. The resulting novel, simply titled Victoria (2016), is in the form of a fictionalized biography of an actual historical person, complete with inner monologue and sincere emotions, which obviously have nowhere been documented in primary sources. The story pays special attention to Victoria's relationships with both her dominant mother and Viscount Melbourne, her first prime minister who lovingly treated her as his own daughter. The story gains a romantic touch when Victoria falls in love with her cousin Albert.

A highly original approach was chosen by David Lagercrantz (born 1962), the Swedish journalist who wrote the sequels to the Millenium trilogy of deceased crime novelist Stieg Larsson. In Fall of Man in Wilmslow (2016), Lagercrantz uses a fictitious policeman to trace the past of the brilliant mathematician Alan Turing, credited to have invented the first computer. Turing played a crucial role in deciphering secret codes used by the German forces during the Second World War, but was after the war prosecuted by the British government for homosexuality and committed suicide in 1954 . The actual historical person in Lagercrantz's novel is therefore no longer alive in the story, yet omnipresent throughout the book. The protagonist is the youthful policeman Leonard Corell who in the course of his exploration of Turing's past discovers that he has more in common with Turing than he had ever imagined.

The short stories of Somerset Maugham and the first novel by Hella Haasse did not by conventional standards qualify as historical novels when they were written since the historical events were unfolding precisely at that time. However, eventually they did acquire the flavor of such fiction by virtue of depicting an actual historical reality that was irretrievably vanishing. All the other works cited here meet the criterion of having been conceived at least fifty years after the historical event.

I believe that our small selection highlights the strength of the historical novel as an independent genre of fiction. Part of the strength lies in the very versatility of the genre, allowing for a variety of ways of combining historical fact and imagined plot. Actual historical events may become anything from background or context to the ultimate target of a quest for insights. Fictitious persons interact with historical persons, play 'first fiddle' or stay in the background, or may even be absent altogether. In all cases, the necessity of paying careful attention to authentic historical detail is underscored.

\section{HISTORIANS TURNING TO FICTION}

There was a time when professional historians looked 
down with unmistakable disdain at novelists using historical materials for their stories, as if the latter were not fully qualified and as if history should remain the exclusive domain of those who had made it their profession. Or, to put it in neutral terms, one was either a historian or a novelist, not both at the same time. I must confess that I for years subscribed to that point of view, wishing to pursue my ambitions in both directions, but not in conjunction with one another. Times have changed and so have I. After having had the privilege of teaching and researching history during four decades and after five novels with a sixth one at press, I am increasingly attracted by the prospect of combining history and fiction.

It is starting to look like a current trend, as British military historian Saul David exclaimed: 'Historians turning their hand to fiction is all the rage' (David, 2010b). This section of the essay presents a selection of seven professional historians, acknowledged experts in their field, who during the past two decades have ventured on writing fiction. Again, there is no pretension at an exhaustive coverage of novelists with a background as professional historians. The selection is strongly geared towards British tradition containing six out of seven writers living in the United Kingdom, supplemented by one single Dutchman. This bias can perhaps be ascribed to a preference among professional historians to write fiction in their native tongue whilst publishing scientific work in English. The selection presented here is also more heavily male-dominated than the selection presented above. Only two of the writers are female. The historians-cum-novelists are ranked in chronological order by their best-known work in the genre.

Leonard Blussé (born 1946) is emeritus professor of overseas history at Leiden University in the Netherlands, specialized in the history of the Chinese in Southeast Asia. He published extensively on, amongst others, the Dutch East India Company (VOC) in the seventeenth and eighteenth centuries. His sole work of historical fiction is the novel Bitter Bonds: A Colonial Divorce Drama of the Seventeenth Century. The award-winning English version appeared in 2002 but had been preceded by a Dutch-language version in 1998. The story is set in late seventeenthcentury Batavia and centers on the heroic struggle of a rich widow, Cornelia van Nijenrode, for divorce from a relentless adventurer from the Dutch Republic called Joan Bitter. ('Bitter' refers both to the husband in Dutch and to the soured relationship in English).
Cornelia van Nijenrode has to endure an uphill struggle considering the subordinate legal and social position of women in the seventeenth century. But at long last, after fifteen years, she gets her divorce. The novel is based on meticulous archival research. It vividly depicts what life was like in the metropolis of the Dutch East India Company in the seventeenth century. The plot makes use of reactions extrapolated from primary sources rather than purely fictitious characters.

Alison Weir (born 1951) is as a writer of popular history without a formal affiliation with an academic institution. She has been extraordinarily prolific, publishing numerous works of non-fiction as well as seven historical novels. She developed a specialization in historical biography, in particular writing about women of importance to British history such as Eleanor of Aquitaine, Queen, first of France, then of England, in the twelfth century. In addition, she wrote on the British royal families and the six wives of Henry VIII. She made her debut as a writer of historical fiction in 2007 with the novel Innocent Traitor about the unfortunate Lady Jane Grey, queen for nine days in 1553. Another six novels have so far followed suit, including a return to Eleanor of Aquitaine in fictionalized form under the title The Captive Queen (2010). The author has continued to pursue her interest in sixteenth-century Tudor England. Recent novels include The Marriage Game about Elizabeth I and the Earl of Leicester (2014) and a fictionalized biography of Anne Boleyn (2017).

Alison Weir has herself admitted that the transition from non-fiction to fiction went smoothly. She is inclined to incorporate a great wealth of detail in her historical novels and does make incidental use of fictitious characters. On The Captive Queen, for instance, no lesser authority than Sarah Johnson noticed that daily life in the twelfth century is described with passion, whereas actual historical figures could have been characterized with more subtleness (Johnson, 2010).

Saul David (born 1966) is professor of military history at the University of Buckingham and a popular presenter of programs on military and imperial matters on British television. He published numerous studies on military personalities and specific military events, notably the Indian mutiny in 1857 and the Allied invasion of Italy in 1943. His career as a writer of historical fiction commenced in 2007 with the novel Zulu Hart, set in a war in South Africa that the same author at an earlier stage had covered in non-fictional 
form. Zulu Hart is the first volume in a series of novels about George Hart, a young soldier of mixed Irish and African descent. In its sequel, Hart of Empire (2010a), protagonist George Hart gets involved in the Second Anglo-Afghan War (1878-1882). The plot of both novels is based on a synthesis of military fact and sometimes romantic fiction. Readers' reactions were mixed but commentators were impressed by the amount and accuracy of military detail.

Simon Sebag Montefiore (born 1965) holds a $\mathrm{PhD}$ in history from Cambridge University. He developed a specialization in Russian history, writing on such diverse figures as for instance Catherine the Great and Stalin. In the meantime, he gained popularity as an acclaimed presenter of historical programs on British television. Although he began publishing historical fiction already in the 1990s, his best-known fictional work is of later date. The novel Sashenka (2008) focuses on the fate of a young woman at the time just before and just after the Russian Revolution in 1917. It is full of emotion and suspense with a wealth of historical detail. The novel was very well received. It was the first volume of a trilogy of dramatic life stories situated in the days of revolution and under Stalin's harsh regime. The sequels are titled One Night in Winter (2013) and Red Sky at Noon (2017). Together, these three novels became known as the 'Moscow Trilogy'. Reviewers praised the accuracy in historical details, whereas, strikingly, fellow historians complained about factual errors in his recent non-fiction work on the history of the Romanov family (Harrison, 2017).

Harry Sidebottom at Oxford University has been publishing both non-fiction and fiction since 1992. His specialization is ancient warfare. He has been extraordinarily prolific in writing historical fiction. Major works include the six-volume series Warrior of Rome series (2008-2013) and the trilogy Throne of the Caesars (2014-2016). The former series is about a fictionalized Anglo-Roman soldier, Marcus Clodius Ballista, who travelled the Roman Empire in the third century. The latter series is set a couple of decades earlier during the short-lived reigns of Alexander Severus and Maximinus Thrax during the 230s, a time of endless intrigues and much bloodshed. The final volume of the series, titled Fire \& Sword was pointedly likened with the fantasy series 'Game of Thrones' with the dragons left out.

Ian Mortimer (born 1967) is affiliated with the universities of Exeter and Reading and a specialist on British medieval and early modern history. He published biographies of Edward III and Henry IV and reached a large, general audience with The Time Traveller's Guide to Medieval England (2008). In recent years he has moved into the genre of historical function, using a pen name, James Forrester. His socalled Clarenceaux trilogy focused on the Elizabethan period and embraced the novels Sacred Treason, Roots of Betrayal and The Final Sacrement (20102012). The plot is set in the 1560 s. The protagonist is William Harley, an actual historical figure, holding the office of 'Clarenceaux King of Arms' in an ancient college of arms in London. As a custodian of Catholic tradition he is torn between loyalties to the crown under the Protestant Elizabeth I and his religion. The trilogy was applauded for its suspense and the author's demonstrated familiarity with the period.

Kate Williams (born 1978) is the sole female writer in our selection of historians turning to fiction. She is professor Public Engagement with History at the University of Reading. Her professional specialization concerned Victorian England and was extended to biographies of women in history, including Elizabeth II. Her career in historical fiction began with the novel The Pleasures of Men (2012). She chose a highly original theme featuring a young woman obsessed by a serial killer in London's East End around 1840. Her subsequent two-volume series was set against the background of the First World War, focusing on an Anglo-German family seeking to survive under exceptional circumstances. These two books were titled Storms of War (2014) and The Edge of the Fall (2015).

This limited selection of historians lured by the charms of fiction demonstrates the wide variety of applicable historical contexts, ranging from the late Roman Empire through Tudor England and the Dutch East India Company to Victorian Britain and recent dictatorship. Above all, the selection underscores the high degree of utility of knowledge acquired in the professional capacity of working as a historian when opting for fiction. Different from novelists using historical material, these writers are not likely to experience difficulties in the quest for authenticity. They may encounter bottlenecks in the vein of drama and style, which brings us to the final topic of this essay, the synthesis of history and fiction.

\section{COMBINING TWO WORLDS}

Historical fiction is not easy. It has been characterized as 'a peculiarly demanding and problematic genre', 
in which the plot negotiates 'between readers' contemporary sensibilities and historical accuracy' (Brown, 1998). The writer of historical fiction is continuously seeking to strike the right balance between the standards of history as a science and the artistic ambitions of fiction. It is the compromise between historical accuracy and literary imagination that makes the genre so demanding but that is also one reason why it carries such a strong appeal to both readers and writers.

Factual accuracy is highly valued in historical fiction. Readers will be disappointed by obvious factual errors, not to speak of reactions by professional historians. This being said, it invites a set of questions of crucial importance to the effort of combining history and fiction in such a way that the outcome is acceptable in both worlds. How do we define historical accuracy? How much historical detail should be provided? How should actual historical figures be handled? And, finally, what kind of historical reality can a novel convey? These four questions need to be touched upon briefly.

Science has come a long way since the adagium of German historian Leopold van Ranke (1795-1886), proclaiming that the task of the historian is to find out 'what has essentially happened' (wie es eigenlich gewezen ist) (Evans, 2000: 17). There is now widespread consensus that history must not be considered as a piece of information of absolute certainty. The historical account is by definition a perception of reality in the past. Although supported by empirical facts, it remains a narrative in itself. And, as we all know, perceptions of the same reality may vary a great deal across observers. The writer of historical fiction needs to be aware of which perception of reality is applicable in fictionalized format. Therefore, the writer needs to view historical sources with a critical eye, just as professional historians are supposed to do. Incidentally, this also implies that serious historical fiction is difficult to reconcile with alt-history (for alternative), where pivotal events are given another outcome than sources tell.

But how much historical detail should there be in story? Excessively much will most likely discourage or bore the reader. An important key consideration is how much readers can be expected to know about the historical events and personalities and the times depicted in the story. Much detail may be necessary when readers are not familiar with the historical background (Fleming, 2004). This point is illustrated by my own experience from writing historical fiction.
I published two short historical stories in successive collective volumes (Lindblad, 2017, 2018). The first one gives an eyewitness account of the assault on a high-ranking court official in the streets of Stockholm in 1810, the second one is set in the second half of the seventeenth century, focusing on the personality of the Swedish king Charles XI. Both were intended for a Dutch readership, not likely to be overly familiar with Swedish history. Therefore, I felt obliged to insert a fair amount of historical detail. The precarious situation of Sweden when Charles XI came of age and seized the reins of power in the 1670s needed to be explained. The same held true for the political events and intrigues preceding the assault on Count Axel von Fersen in 1810. Difference from general practice with historical fiction, the publisher of the collective volumes wished to add a non-fictional appendix to each contribution, highlighting the historical facts. In the full-fledged historical novel, it remains a challenge for the author to incorporate sufficient background information in the plot itself.

Another consideration refers to the very function of historical detail in the story. The idea is not to demonstrate the author's wide knowledge of history but rather to submerge the reader into a fascinating past offering a measure of familiarity that was not there before reading the story. Period detail is important, not in itself but because it renders a stronger sense of authenticity to the story (David, $2010 b$ ). That is also why a top priority needs to be attached to accuracy in historical detail.

Actual historical persons are indispensable when mixing history and fiction, but how do we go about them? Again, much depends on how familiar the historical persons are to readers and what their function is in the plot. Widespread previous knowledge about a historical person tends to reduce the degrees of freedom available to the author in depicting the person. Do the historical persons serve as minor figures in the plot, next to fictitious protagonists, or does the author aim at a fictionalized biography? The former approach is in the line of Simon Sebag Montefiore, where the latter one was successfully applied by Hilary Mantel with respect to Thomas Cromwell. Special caution needs to be exercised when expressing thoughts and emotions by persons who have actually lived. Whenever the author writes 'he thought' or 'she felt', it is clear that it is the author's imagination at work. Historical figures should at all times stay true to the spirit of the person (Mantel, 2009a). This is only achieved by careful and critical study of preserved 
documents such as letters and diaries.

Historical fiction conveys a certain historical reality, which inevitably deviates from actual or perceived historical reality. The author has been compelled to take liberties with the historical facts in order to make the story fit the format of fiction. Saul David urges historical novelists to be restrictive when applying such liberties. To this opinion, the story should stay closely to perceived historical truth, thus offering readers with a kind of history as it could conceivably have looked like (David, 2010b). This translates as an overall guideline for almost any kind of historical fiction, whilst ruling out an all too liberal use of the author's own imagination.

Historical fiction flourishes by virtue of attractive narratives, as opposed to the kind of painstaking and systematic analysis characteristic of much of the historical science. Current popularity with historical fiction, not only in novels but even more so in adaptations for the screen, has encouraged the narratization of history at large. An acknowledged specialist on the historical novel as a genre, Jerome de Groot, even spoke of a tendency towards 'perverting history' (De Groot, 2015). It is apparent that not all branches of the historical science lend themselves readily for fiction. The narrative carries a strong appeal to the general public. Yet readers and viewers are easily left with a somewhat distorted perception of what history is all about.

Costly television series, intended for a mass audience, are currently making a highly significant contribution towards popularizing history and supporting the genre of historical fiction. The issue of accuracy of historical fact is brought to a head when historical events and persons are displayed on the screen rather than being derived from the author's description. A notorious example is the television series Vikings, already into its sixth season at Britain's History Channel. The series was charged with blatant inaccuracies in the very appearance of the Vikings (Wallace, 2016).

Other celebrated adaptations for television include BBC's mini-series Wolf Hall in 2015, the French-Canadian joint venture Versailles with two completed seasons (2015-2017) and Netflixproduction The Crown, also with two completed seasons so far (2016-2017). A few scattered observations on the latter two appear relevant in the context of the preceding discussion about the importance of accuracy in historical detail.

Versailles pictures personal life and immediates of Louis XIV in the late 1660s and early 1670s. Historical figures are freely mixed with fictitious characters and there is so much explicit sex and violence that viewers inadvertently are reminded of the Game of Thrones. The true essence of the elaborate plot lies in the relationship between the two brothers, Louis XIV, brother and king, and Philip of Orleans, only brother, and the most famous openly gay man of the seventeenth century. This highly complex relationship is depicted with a great sense for drama. Still, a few unnecessary modifications of the historical reality were made. For instance, the two brothers realized how strong their mutual bond in fact was, not at the deathbed of Philip's wife Henriette in 1673 as in the series but at the more likely moment of their mother's deathbed in 1665. Also, Philip's sincere deep concern about the health of his brother was not when they were adults as shown, but at an earlier stage when they were teenagers and arguably more prone to emotional outbursts (Barker, 1989).

A pivotal scene in the second season of Versailles features an extraordinary conversation between Louis XIV and his main adversary, the far younger and more naïve William of Orange, situated in a monastery in Utrecht during the vain attempt by Louis XIV to invade the Dutch Republic in 1672. Again, the viewer gets great drama. The only problem is that this meeting never took place. Few producers of historical fiction have taken as much liberties with historical fact as the makers of Versailles.

The first two seasons of The Crown follow Elizabeth II from her marriage to Prince Philip in 1947 to the mid-1960s. The series shows restraint in presenting scenes that may cause offense, especially where still living historical persons are involved. It appears faithful to historical accuracy and rightly keeps away from speculations about extramarital activities of Prince Philip. As in all fictionalized contemporary history, the actual historical figures are by appearance well-known to viewers, which makes appropriate casting absolutely crucial. In The Crown the casting was highly successful for Churchill, but far less so for Kennedy.

The producer of historical fiction, in writing or for the screen, can choose between different approaches with respect to handling the issue of accuracy in historical detail. The most cautious one is to introduce a fictitious person who observes an historical event or a historical person. This is the approach I myself chose in my two short historical stories cited above. It is a safe way to avoid the pitfalls 
of disputable interpretations, let alone factual errors. One step further is to step into the mind of an actual historical person, reproducing talk, thoughts and emotions as best as possible. Daisy Goodwin opted for this solution when writing about the young Queen Victoria. However, her intimate involvement with the protagonist presupposed a liberal use of her own imagination. This implied making the most of the young woman's virtual infatuation with her far older Prime Minister, Melbourne, which in turn implied ignoring Albert, her later husband. In the novel Victoria changes her mind improbably fast. It is not commensurate with historical fact as Victoria's warm feelings for Albert are reported to date from before she became queen (Strachey, 1921).

A third option is the one chosen in Versailles The timing of key moments is altered and historical events are even invented. There is room for unfounded allegations as in the case of the presumed implication by Madame de Montespan in the series of poisoning at Versailles in the 1760s. Although taking such liberties does expand the scope for fictional drama, it fails to do full justice to history.

These three options are at the disposal of both the novelist wishing to use history and the professional historian wishing to become a novelist. All three have their shortcomings and advantages. In the final analysis, it is the author who decides which path to choose.

\section{CONCLUSION}

These reflections on the combination of history and fiction have brought to light a number of observations about historical fiction as a genre in its own right. The genre has demonstrably great potential precisely on account of its twin origins in historical science and fiction as an artistic expression. A limited selection of writers has highlighted the impressive versatility of novelists using historical materials within widely different national traditions of literature. Another limited selection of writers has underscored a similar versatility within the more recent trend of professional historians turning novelists. A further digression of the possibilities of combining history and fiction emphasized the crucial point of accuracy in historical detail. This digression ended with a differentiation of how to combine history and fiction, ranked by level of accuracy of detail and direct involvement by the author in the historical scenery. Historical fiction remains 'peculiarly demanding and problematic'.
Perhaps that is part of the charm it holds for those engaging in it.

\section{REFERENCES}

Adamson, Lynda G. (1999). World Historical Fiction. Phoenix, AZ: Onxy Press.

Barker, Nancy Nichols (1989). Brother to the Sun King: Philippe, Duke of Orléans. Baltimore: Johns Hopkins University Press.

Blussé, Leonard (1998/2002). Bitters bruid: Een koloniaal huwelijksdrama in de Gouden Eeuw (Bitter Bonds: A Colonial Divorce Drama of the Seventeenth Century). Amsterdam: Rainbow Pocketboeken; Princeton, NJ: Markus Wiener Publishers.

Brown, Joanne (1998). Historical Fiction or Fictionalized History? Problems for Writers of Historical Novels for Young Adults, Alan Review, 26(1).

David, Saul (2007). Zulu Hart. London: Hodder \& Stoughton.

David, Saul (2010a). Hart of Empire. London: Hodder $\&$ Stoughton.

David, Saul (2010b). 'Tell tales from history: Are historians best placed to write historical fiction?', The Independent 12 August.

Evans, Julian (2010). 'The tea lords by Hella Haasse review', The Guardian 4 December.

Evans, Richard (2000). In Defense of History. London Granta Books.

Fleming, Paul (2004). 'Blending fiction and history' on writing-world.com.

Goodwin, Daisy (2016). Victoria: A Novel of a Young Queen. New York: St. Martin's Press.

Groot, Jerome de (2010). The Historical Novel. London/ New York: Routledge.

Groot, Jerome de (2015). Remaking History: The Past in Contemporary Historical Fiction. London/New York: Routledge.

Haasse, Hella (1948/2013). Oeroeg (The Black Lake). Amsterdam: Vereeniging ter Bevordering van de Belangen des Boekhandels; London: Portobello Books.

Haasse, Hella (1992/2010). Heren van de Thee (The Tea Lords). Amsterdam: Querido; London: Portobello Books.

Harrison, Dick (2017). 'Den sista tsardynastin: Romanov 1613-1918. Groteska sakfel om tsardynastin' [The last dynasty of the tsars: Romanov, 1613-1918. Bizarre factual errors about the dynasty of the tsars']. Svenska Dagbladet [Stockholm], 11 June.

Hastings, Selina (2009). The Secret Lives of Somerset Maugham: A Biography. London: John Murray. 
Johnson, Sarah L. (2002). 'Defining the genre: What are the rules for historical fiction'. Speech at the annual meeting of the Association of Writing Programs, March.

Johnson, Sarah L. (2005). Historical Fiction: A Guide to the Genre. Westport, CT: Libraries Unlimited.

Johnson, Sarah L. (2009). Historical Fiction II. Westport, CT: Libraries Unlimited.

Johnson, Sarah L. (2010). 'A queen for all seasons', The Globe and Mail, 26 May.

Kurniawan, Eka (2002/2015). Cantik Itu Luka (Beauty Is a Wound). Yogyakarta: AKY Press; London: Pushkin Press.

Kurniawan, Eka (2006). Pramoedya Ananta Toer dan Sastra Realisme Sosialis. Jakarta: Gramedia Pustaka Utama.

Lagercrantz, David (2016). Fall of Man in Wilmslow: A Novel of Alan Turing. London: Quercus Publishing.

Lee, Richard (no date). 'Defining the Genre', Historical Novel Society [historicalnovelsociety.org].

Lindblad, Thomas $(2017,2018)$. ). 'Jong en van adel' (2017, 'Young and of noble birth'); 'In de schaduw van Tre Kronor' (2018, 'In the shadow of Three Crowns'). In: Historische Verhalen. 27 korte geschiedenisverhalen. Verzamelbundel I ['27 historical short stories, Volume I'] (2017); 20 korte geschiedenisverhalen. Verzamelbundel II ['20 historical short stories. Volume II']. Leiden: Uitgeverij Historische Verhalen.

Lukacs, György (1983). The Historical Novel. Lincoln, NE: University of Nebraska Press. [First published in Russian in 1937 and in English in 1969].

Mantel, Hilary (2009a). 'Booker winner Hilary Mantel on dealing with history in fiction', The Guardian 17 October.

Mantel, Hilary (2009b). Wolf Hall. London: Harper Collins.

Mantel, Hilary (2012). Bring Up the Bodies. London: Harper Collins.

Maugham, W. Somerset (1926). The Casuarina Tree. London: Heinemann.
Maugham, W. Somerset (1933). Ah King. London: Heinemann.

Mortimer, Ian (2008). The Time Traveller's Guide to Medieval England. London: The Bodley Head.

Mortimer, Ian (2010-2012). Sacred Treason (2010), Roots of Betrayal (2011) and The Final Sacrement (2012). London: Headline Publishing.

Pramoedya Ananta Toer (1980-1988). Bumi Manusia (This Earth of Mankind, 1980), Anak Semua Bangsa (Child of All Nations, 1980), Jejak Langkah (Footsteps, 1985), Rumah Kaca (House of Glass, 1988). Jakarta: Hasta Mitra; Penguin Books.

Sebag Montefiore, Simon (2008-2017). Sashenka (2008), One Night in Winter (2013), Red Sky at Noon 2017). New York: Simon \& Schuster; Harper Collins; Random House.

Sidebottom, Harry (2008-2013). Warrior of Rome. 6 vols. London: Michael Joseph Publishers/Penguin Books.

Sidebottom, Harry (2014-2016). Throne of the Caesars. 3 vols. London: Harper Collins.

Strachey, Lytton (1921). Queen Victoria. New York: Harcourt, Brace and Co.

Wallace, Sam (2016). 'Film meets fact - why is historical accuracy important?'. Nouse, 13 January.

Weir, Alison (2007). Innocent Traitor: A Novel of Lady Jane Grey. New York: Ballantine Books.

Weir, Alison (2010). The Captive Queen: A Novel of Eleanor of Aquitaine. New York: Ballantine Books.

Weir, Alison (2014). The Marriage Game: A Novel of Elizabeth I. New York: Ballantine Books.

Weir, Alison (2017). Anne Boleyn: A King's Obsession. New York: Ballantine Books.

Williams, Kate (2012). The Pleasures of Men. London: Penguin Books.

Williams, Kate (2014-2015). The Storms of War (2014), The Edge of the Fall (2015). London: Orion Publishers.

Zwigtman, Floortje (2005-2010). Schijnbewegingen (2005), Tegenspel (2007), Spiegeljongen (2010). Baarn: De Fontein. Translations into German available. 